\title{
ANALISIS ALGORITMA K-MEDOIDS CLUSTERING DALAM PENGELOMPOKAN PENYEBARAN COVID-19 DI INDONESIA
}

\author{
Sukma Sindi, Weni Ratnasari Orktapia Ningse, Irma Agustika Sihombing, P.P.P.A.N.W \\ Fikrul Ilmi R.H.Zer, Dedy Hartama \\ Program Studi Teknik Informatika, STIKOM Tunas Bangsa Pematangsiantar, \\ Jl. Jend. Sudirman Blok A No.1,2 dan 3, Kota Pematangsiantar 21111 - Indonesia \\ skmsindiegmail.com, weni.oktapia21@gmail.com, Irmasihombibg006egmail.com, \\ fikrulilmizer@gmail.com, dedyhartama@amiktunasbangsa.ac.id
}

\begin{abstract}
At the beginning of March Indonesia was entering the corona outbreak virus (COVID) Every day the case of Covid-19 distribution in Indonesia continued to increase. the community is issued to conduct social distance to cut the distribution of COVID-19 distribution distributed in various regions. In Indonesia, therefore, the data that has been accommodated is certainly a lot, from the data it can be seen patterns - selection patterns of distribution of COVID-19 distribution are based on test scores, This study uses the $K$-Medoids method so that the distribution patterns of COVID-19 distribution can be used for the community. K-Medoids is a method of grouping Analytical sections that aim to get a set of kclusters among the data that most require an object in the collection of data. The results of the new COVID-19 research grouping show the community produced from various regions in Indonesia. Characteristics with a body temperature above $36.9 \circ \mathrm{c}$ and with fever and cough resolution supported by one of the characteristics of COVID-19 symptoms.
\end{abstract}

Kata Kunci - K-Medoids Algorithm, Clustering, Data Mining, COVID-19, Data Grouping

\begin{abstract}
Abstrak - Pada awal maret Indonesia sedang di landa masuknya wabah virus corona (covid) Setiap hari kasus penyebaran covid-19 di indonesia terus meningkat. masyarakat diminta untuk melakukan social distancing guna mamutus rantai penyebaran covid-19 yang tersebar diberbagai wilayah.di Indonesia. Oleh karena itu, data yang telah ditampung pastinya banyak sekali, dari data tersebut dapat dilihat pola - pola penentuan pengelompokan penyebaran covid-19 dilakukan berdasarkan nilai tes, Penelitian ini menggunakan metode $K$-Medoids agar dapat diketahui pola pemilihan penentuan pengelompokan penyebaran covid-19 bagi masyarakat. K-Medoids merupakan metode Analitis partisional clustering yang bertujuan untuk mendapatkan suatu set $k$-cluster di antara data yang paling mendekati suatu objek dalam pengelmpokan suatu data.. Hasil penelitian pengelompokan penyebaran covid-19 baru menunjukkan bahwa masyarakat yang berasal dari berbagai wilayah di Indonesia. Cirri-ciri dengan suhu badan di atas 36,9॰ c dan dengan disertai demam dan batuk berkelanjutan menunjukkan salah satu ciri-ciri gejalah covid-19
\end{abstract}

Kata Kunci - Algoritma K-Medoids, Clustering, Data Mining, Covid-19, Pengelompokan Data

\section{PENDAHULUAN}

Diawal maret 2020 Indonesia sedang dilanda pandemi covid-19, virus ini pertama kali muncul di wilayah wuhan-tiongkok ditemukan pada akhir desember 2019. pemerintah dan masyarakat sedang melakukan social distancing guna memutus rantai penyebaran covid-19 yang terus meningkat setiap harinya. Penularan Covid-19 hanya bisa dicegah dengan kedisiplinan untuk tetap berada di rumah. Risiko penularan pun bisa terhindarkan dan masalah Covid-19 di Indonesia bisa segera diatasi kebijakan yang paling baik. Total keseluruhan penyebaran covid19 di Indonesia saat ini mencapai 14,265 jiwa untuk kasus penyebaran sembuh covid-19 di Indonesia mencapai 2.881 jiwa dan angka kematian mencapai 991 jiwa. Penelitian ini menggunakan metode
Penerapan K-Medoids agar dapat diketahui pola pemilihan penentuan pengelompokan penyebaran covid-19 di berbagai wilayah di indinesia. K-Medoids merupakan metode partisional clustering dimana bertujuan untuk menemukan satu set $k$-cluster di antara data yang paling mencirikan objek dalam kumpulan suatu data.

\section{A. Data Mining}

Data mining adalah sebuah proses pencarian secara otomatis informasi yang berguna dalam tempat penyimpanan data berukuran besars. Data mining adalah analisa terhadap data untuk menemukan hubungan yang jelas serta menyimpulkannya yang belum diketahui sebelumnya dengan cara terkini dipahami dan berguna bagi pemilik data tersebut[1]. 
Descriptive mining, yaitu proses untuk menemukan karakteristik penting dari data dalam satu basis data. Teknik data mining yang termasuk descriptive mining adalah clustering, asosiation, dan sequential mining [2].

\section{B. Clustering}

Clustering merupakan suatu proses pengelompokkan record suatu, observasi, atau mengelompokkan kelas yang memiliki kesamaan objek. Perbedaan clustering dengan klasifikasi yaitu tidak adanya variabel target dalam melakukan suatu pengelompokan pada proses clustering. Clustering sering dilakukan sebagai untuk langkah awal dalam proses data mining saat melakukkan suatu metode analisis. Terdapat banyak algoritma Clustering yang telah digunakan oleh peneliti sebelumnya seperti $K$ Means, Improved K-Means, Fuzzy C-Means, DBSCAN, K-Medoids (PAM), CLARANS dan Fuzzy Substractive. Setiap algortima memiliki kelebihan dan kekurangan masing-masing, namun prinsip algoritma sama, yaitu mengelompokkan data sesuai dengan karakteristik dan mengukur jarak kemiripan antar data dalam satu kelompok [3].

\section{Algoritma K-Medoids}

$K$-Medoids merupakan suatu algoritma yang digunakan untuk menemukan medoids didalam sebuah kelompok (cluster) yang merupakan titik pusat dari suatu kelompok (cluster). Algoritma $K$-Medoids lebih baik dibandingkan dengan $K$-Means karena pada $K$ Medoids kita menemukan $k$ sebagai objek yang representatif untuk meminimalkan jumlah ketidaksamaan objek data, sedangkan pada $K$-Means menggunakan jumlah jarak euclidean distances untuk objek data[4]. Langkah-langkah algoritma $\mathrm{K}$-Medoids sebagai berikut:

1. Inisialisasi pusat cluster sebanyak $k$ (jumlah cluster).

2. Alokasikan setiap data (objek) ke cluster terdekat menggunakan ukuran jarak Euclidean Distance dengan persamaan: $\mathrm{x}$

$$
\begin{aligned}
& \sum_{i=1}^{n}(i \dot{i} i-y i)^{2} ; 1,2,3, \ldots . n d \\
& (x, y)=i \vee x-y \vee i=V_{i}
\end{aligned}
$$

3. Pilih secara acak objek pada masing-masing cluster sebagai kandidat medoid baru.

4. Hitung jarak setiap objek yang berada pada setiap masing-masing cluster dengan menempuh medoids baru.

5. Hitung total simpangan (S) dengan menghitung nilai total distance baru - total distance lama.
Jika $\mathrm{S}<0$, maka ganti objek dengan data cluster untuk memperoleh sekelompok $k$ objek yang baru sebagai medoids.

6. Ulangi tahap ke 3 sampai 5 hingga tidak terjadi perubahan medoid, sehingga didapatkan cluster beserta anggota cluster masing-masing. Kemudian untuk mendapatkan nilai $\mathrm{k}$ di sebuah data yang ada di clustering K-Medoid dilakukan di dalam proses clustering dapat dipilih dengan bersasarkan nilai DBI (Davies Bouldin Index) terkecil.

\section{METODE PENELITIAN}

Dalam metode ini cara untuk memperoleh dan mengumpulkan data-data ilmiah yang dibutuhkan dengan fungsi dan tujuan tertentu. Metode penelitian dapat dilihat pada gambar 1(Juninda and Andri, 2019)

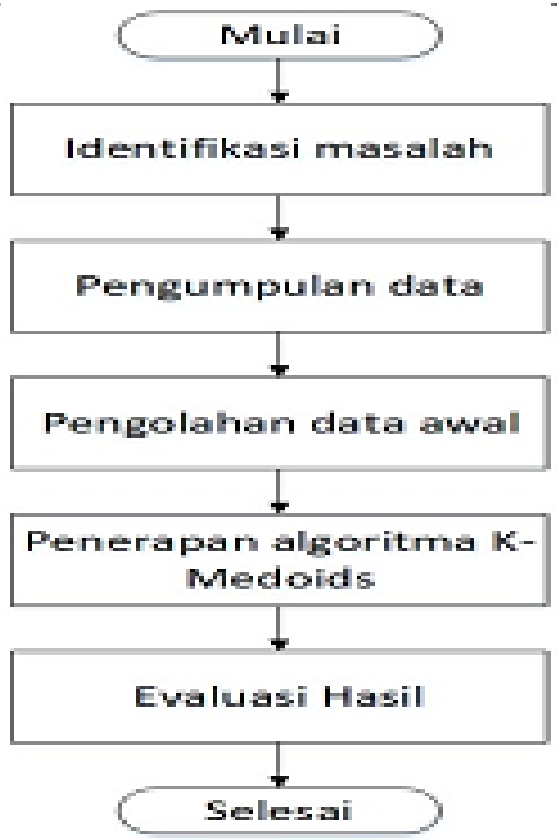

Gambar 1. Metode Penelitian

\section{A. Identifikasi Masalah}

Dalam penelitian ini, identifikkasi masalah bertujuan untuk mengetahui seberapa banyak pengelompokan pada masalah kasus covid-1 di Indonesia menggunakan metode $K$-Medoids Clustering . Dan mencari akar masal dengan table data yang kita punya dengan table yang kita miliki tersebut melonjaknya angka penyebaran wabah menjadi akar pokok permasalahan ini.

\section{B. $\quad$ Pengumpulan Data}

Pada pengumpulan Data dilakukan dari objek yang kita telitih dimana data yang kita peroleh dari Kementrian Kesehatan Indonesia. Data yang 
digunakan menggunakan 3 variabel yaitu, kasus positif, kasus sembuh, dan kasus meninggal.

\section{Pengolahan Data awal}

Dari data yang sudah kita miliki, kemudian akan kita olah dengan menggunakan metode $\mathrm{K}$ Medoids Clustering. Untuk mengetahui pengelompokan data sehingga data akan menampilkan hasil akhir dari pengelompokan Clustering.

\section{Penerapan Algoritma K-Medoids}

Algoritma K-Medoids biasa disebut sebagai partitioning around medoids, yang merupakan varian dari metode K-Means. Hal ini didasarkan pada penggunaan medoids bukan dari pengamatan mean yang dimiliki setiap clulster, yang bertujuan untuk mengurangi sensitivitas dari partisi yang dihasilkan sehubungan dengan nilai-nilai ekstrim yang ada pada dataset. Algoritma K-Medoids merupakan suatu algoritma yang mengatasi kelemahan Algoritma KMeans yang sensitif terhadap outlier karena objek dengan suatu nilai yang besar mungkin menyimpang dari distribusi data. Untuk perhitungan menggunakan algoritma $K$-Medoids dapat mengikuti langkah 1 sampai 6 seperti yang sudah dijelaskan sebelumnya. Dengan melakukan percobaan tiga cluster $(\mathrm{k}=3)$, sehingga didapatkan grafik perbandingan jumlah item 3 cluster.

Dalam Proses Perhitungan pada metode KMedoids berikut langkah-langkahnya sebagai berikut

1. Melakukan normalisasi data yang akan digunakan dalam proses perhitungan KMedoids. Perhitungan normalisasi data menggunakan persamaan (1)

2. Menginisialisasikan pusat cluster secara acak, kemudian menghitung jarak data (objek) dengan pusat cluster menggunaka suatu Euclidean Distance. Dalam perhitungan Euclidean Distance menggunakan persamaan (2)

3. Menghitung total distance dari keseluruhan data di dalam cluster.

4. Menginisialisasikan pusat cluster baru secara acak kemudian menghitung jarak data (objek) dengan pusat cluster dengan Euclidean Distance. Perhitungan Euclidean Distance menggunakan persamaan (2).

5. Untuk menentukan atau menetapkan selisih total distance dengan mengurangi total distance baru total distance lama.

6. Setelah itu untuk mendapatkan hasil cluster akhir, menghitung nilai average dissimilarity (ai) untuk penilaian (evaluasi) dengan metode silhouette coefficient. Perhitungan a(i) menggunakan persamaan (3)
7. Jika menetapkan dari perhitung nilai lowest average dissimilarity (bi). Perhitungan b(i) menggunakan persamaan (4).

8. Untuk menghitung nilai silhouette coefficient (si). Perhitungan s(i) melakukan persamaan untuk mengenal mutu terbaik dari cluster.

\section{HASIL DAN PEMBAHASAN}

\section{A. Perancangan}

Pada proses perancangan yang akan dlakukan pada algoritma K-Medoids, dengan memasukkan jumlah data yang dibutuhkan dalam proses untuk menentukan jumlah clustering. Proses selanjutnya perhitungan seluruh di jaringan $\mathrm{K}$ medoids. Pada hasil akhir akan menampilkan grafik/plot view nya didalam sebuah hasil perhitungan di rapid miner 5.3

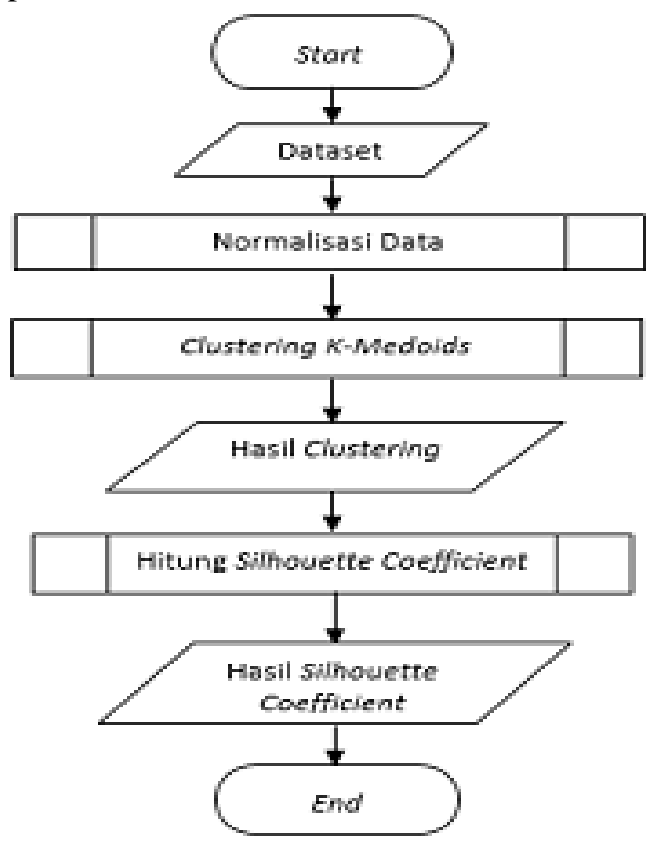

Gambar 2. Perancangan Perangkat Lunak

\section{B. Data Awal}

Data awal/sumber data yang digunakan dalam penelitian ini langsung dari kementrian kesehatan Indonesia. Data yang kami gunakan dalam penelitian yaitu alur grafik penyebaran covid-19 yang terjadi saat ini di Indonesia khususnya, dimana data ini menggunakan 34 provinsi yang ada di Indonesia. akan di kelompokkan di untuk menentukan clustering 1, 2, dan 3. Data penyebaran Covid-19 meliputi kasus positif, sembuh, dan meninggal. Berikut yaitu cara menentukan data / pengelompokan data. 


\section{Dashboard Kasus COVID-19 di Indonesia 2020-03-02 s/d sekarang}

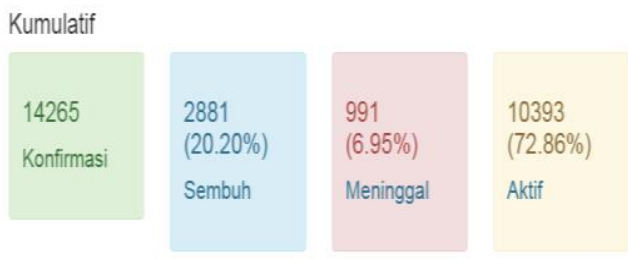

Gambar 3. Data Covid-19

Pada data ini tingkat penyebaran yang terkonfirmasi positive covid ialah 14265 ribu jiwa, sembuh dari covid ada 2881 jiwa dan meninggal ada 991 diupdate sampai tanggal 11 mei 2020. Dari awal masuk corona virus (covid) ini di Indonesia mengalami peningkatan sejak awal ter identifikasi virus ini berbagai upaya pemerintahan Indonesia untuk mencegah penyebaran virus ini namun, kita juga harus patuh pada aturan pemerintah. Berikut adalah grafik peningkatan covid-19 di Indonesia. Penyebaran Kasus Konfirmasi CoviD-19 di Indonesia Pusat Data dan Informasi, Kementerian Kesehatan Highest towest

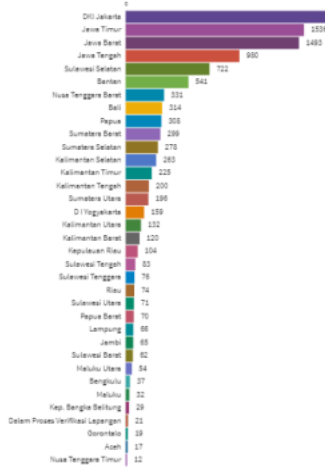

Gambar 4. Diagram Kasus Positif

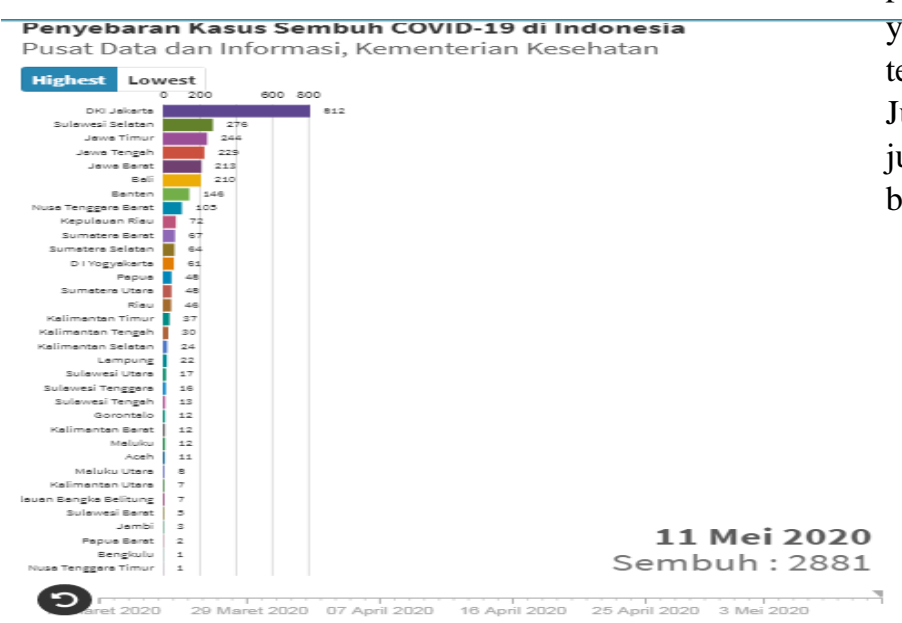

Gambar 5. Diagram Kasus Sembuh

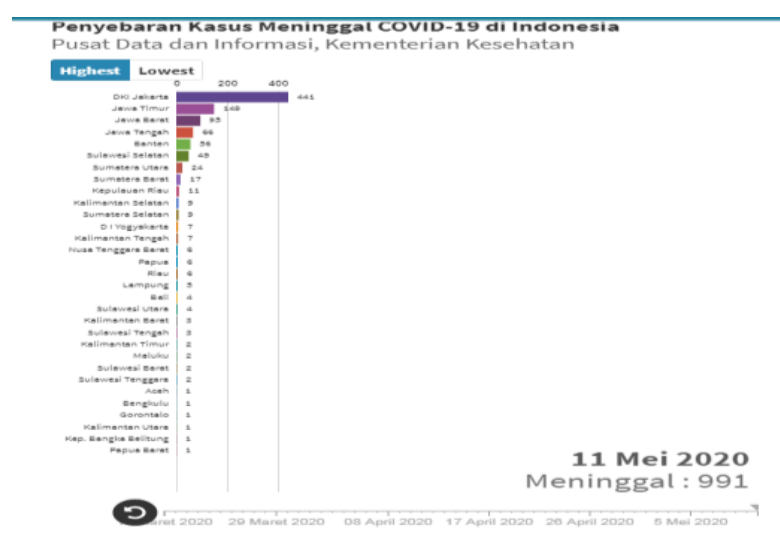

Gambar 6. Diagram Kasus meninggal

Dibawah ini adalah titik penyebaran Covid-19 dimana da 34 provinsi diindonesia.

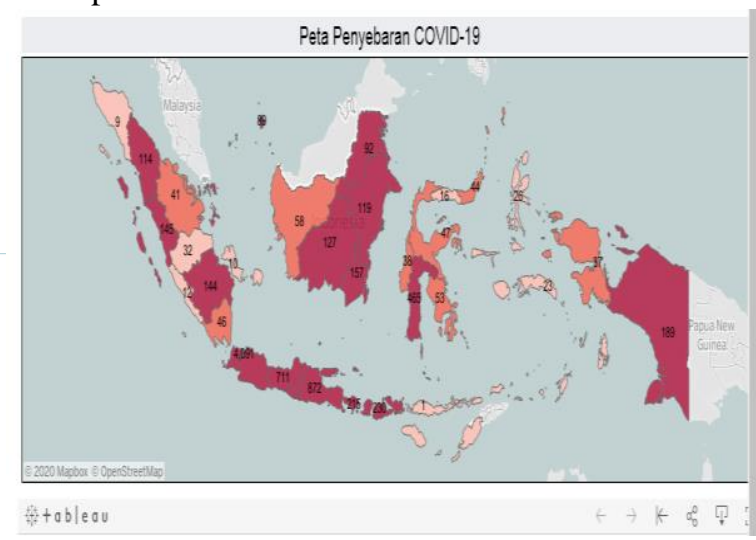

Gambar 7. Peta Penyebaran Covid di Indonesia

C. Hasil Analisa Pengujian

1. Masukan Proses Data

Pengumpulan input dataset excel di sejumlah wilayah yang terjangkit positif oleh covid, dalam proses data disini terdapat 2 tipe data masukan yaitu jumlah data 34 provinsi yang terjangkit/positive covid-19, dan jumlah cluster. Jumlah cluster disini ada 3 Clustring. Dimana jumlah setiap wilayah yang terpapar berbedabeda. 


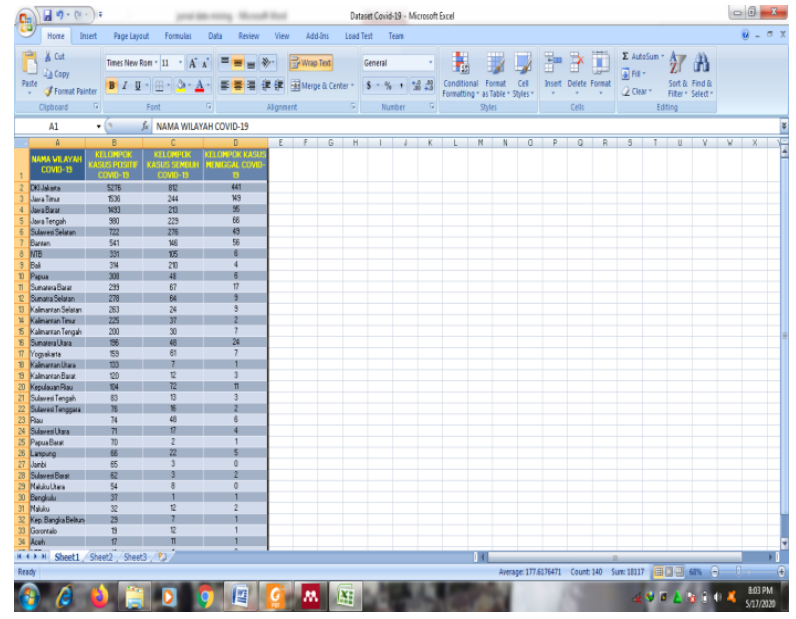

Gambar 8. Penyebaran di provinsi

Kemudian kita akan memproses dataset excel tadi mengunakan software Rapid Miner 5.3. untuk mengetahui penelompokan jumlah cluster yang didapat. klik new proses seperti tampilan dibawah ini.

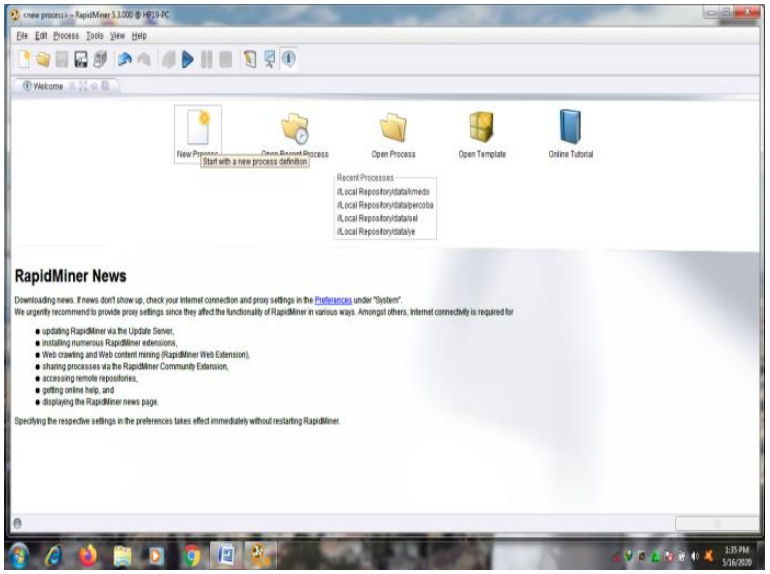

Gambar 9. proses pengolahan data

Lalu akan menampilkan tampilan proses seperti di bawah ini. Kemudian masukkan data yang akan di diproses ke lembar kerja. Dibagian kiri paling bawah klik symbol segitiga kebawah warna hitam klik (import excel sheet). Setelah kita klik import akan muncul tampilan seperti dibawah ini data set yang akan kita import dengan atribut yang sudh kita buat untuk menegtahui titik clustering yang kita butuhkan. klik data yang akan kita proses selanjutnya kemudian next.

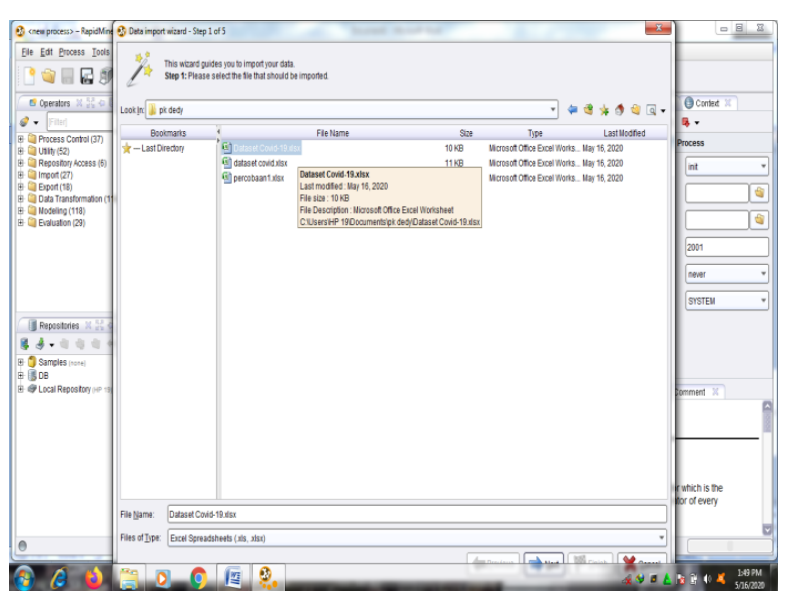

Gambar 10. step 1 import data excel.

Kemudian tampil seperti gambar dibawah ini, disini tidak ada yang perlu di ubah klik next saja. Masih sama disini belum ada perubahan yang harus diubah, hanya saja variabelnya yang berubah. Perhatikan gambar dibawah ini kemudian di Next sampai proses step ke 3 tidak ada perubahan yang harus diubah Next.

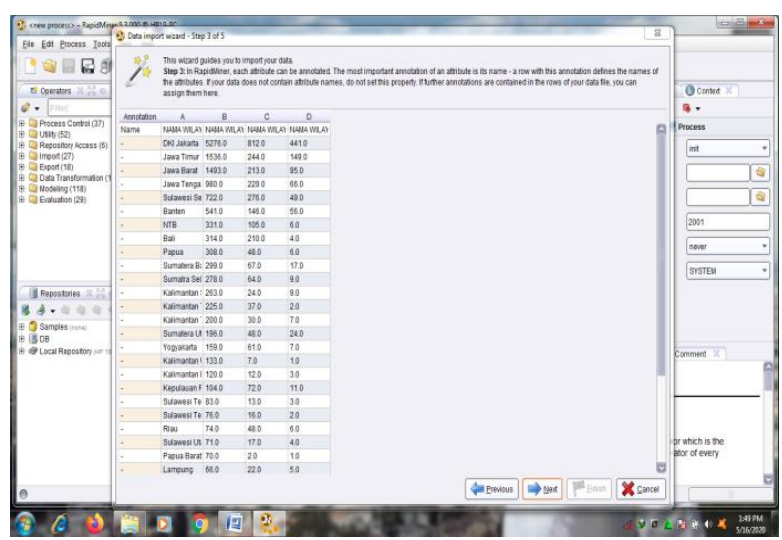

Gambar 11. Step 3 Import Data Excel

Perhatikan pada Gambar dibawah ini :

1. di bagian integer khusus wilayah covid (binominial) diubah menjadi (nominal)

2. dan di bagian (atribut) juga diganti/ dipilih menjadi (id). Kenapa diganti menjadi, karna untuk nama wilayah atau daerah mempunyai kunci tersendiri agar terindentifikasi nama wilayah tersebut.

3. Untuk dibagian yang lain biarkan saja tanpa ada perubahan sama sekali

4. Next 


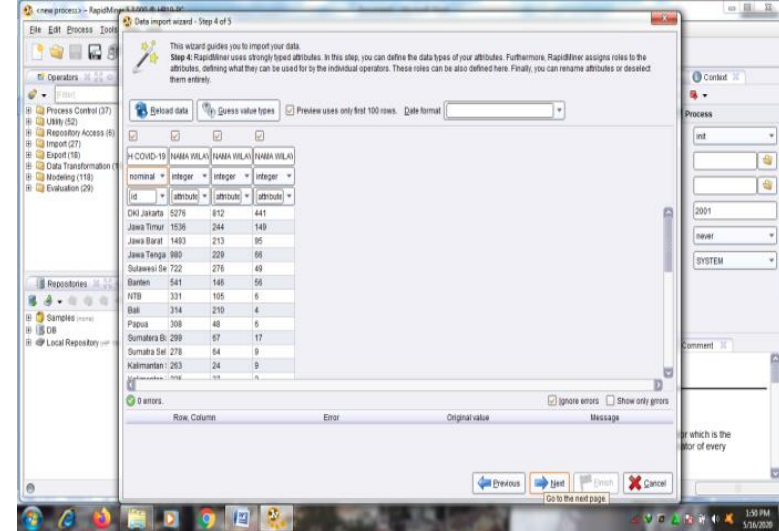

Gambar 12. Step 4 Import Data Excel

Kemudian simpan Data yang sudah kita ubah tadi perhatikan langkah-langkah pada gambar di bawah ini.

1. di (data)

2. buat file name yang akan disimpan

3. finish

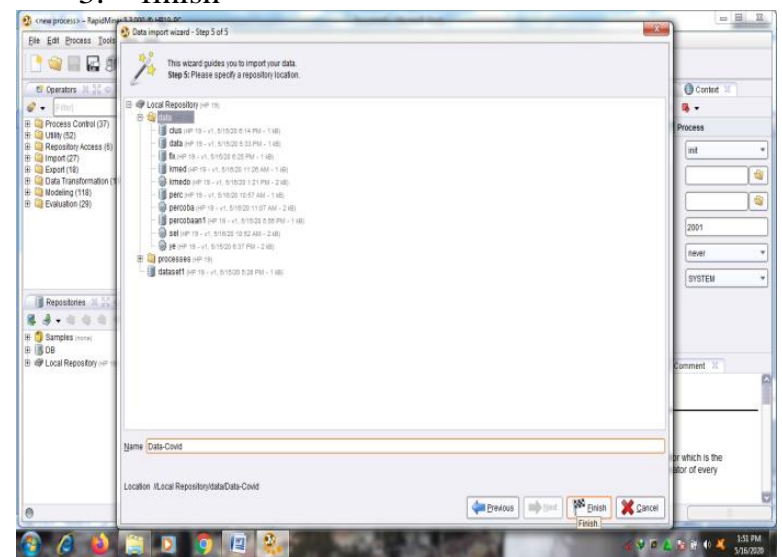

Gambar 13. Step Import Data Wizard Selesai

Nah tampilan dibawah ini, tampilan dari Data View yang sudah siap kita proses selanjutnya untuk menerapkan $\mathrm{K}$-Medoids.

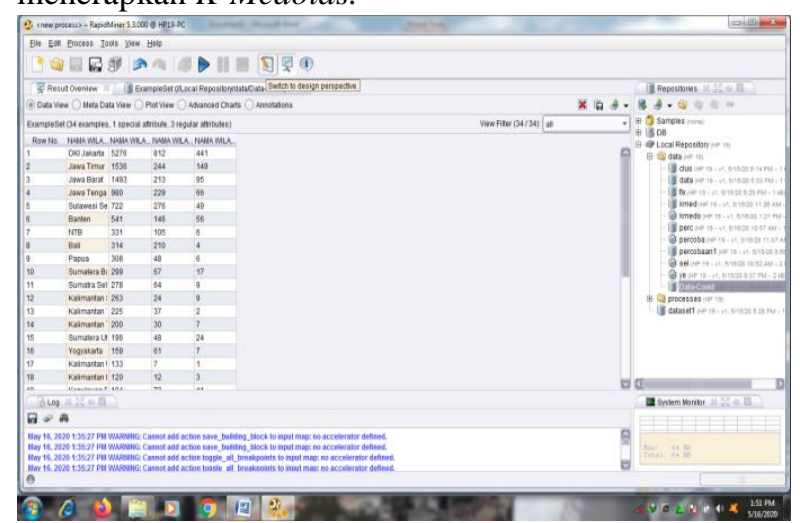

Gambar 14. Proses Import Berhasil

b. masukan penerapan Metode k-medoids

Disini kita akan menarik/drag data yang sudah kita simpan tadi dibagian bawah sebelah kiri. contoh filedata dalam penelitian yang digunakan disini Data-Covid. Kemudian tarik Data-Covid tersebut ke lembar kerja yang ada ditengah seperti dibawah ini

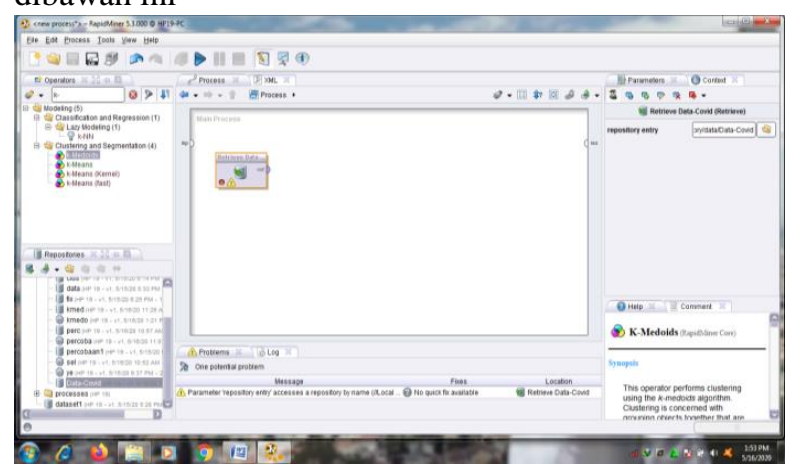

Gambar 15. Input Data-Covid

Tahap berikutnya disini yang paling penting menggunakan K-Medoids, karna penelitian ini menggunakan K-Medoids.

1. klik dibagian atas sebelah kiri cari/share (Modelling, Clastering and segmentation, KMedoids)

2. di drag atau di tarik K-Medoids yang ada di tengan lembar kerja

3. kemudian hubungkan garis tersebut dengan benar.

4. Kemudian jalankan / run di atas dengan symbol segitiga warna biru

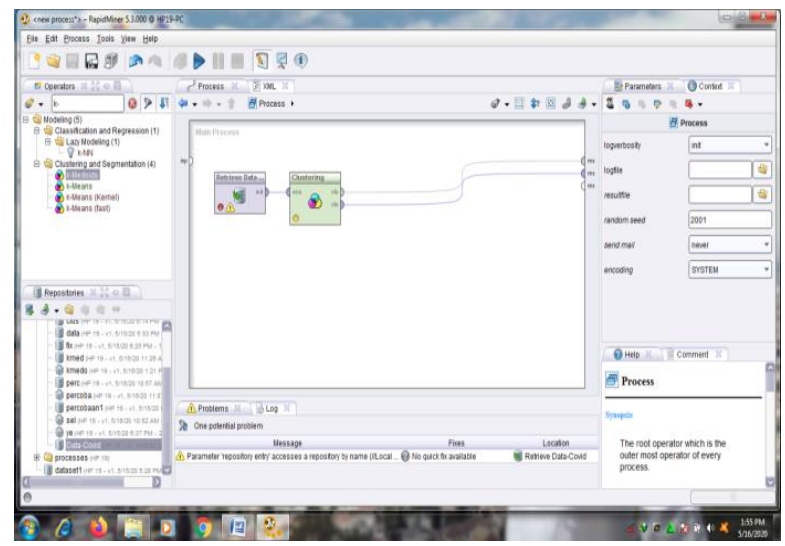

Gambar 16. clustering (K-medoids)

Proses run akan berjalan dengan baik jika tampilan data muncul pada saat run berhasil Data View seperti gambar dibawah ini. 


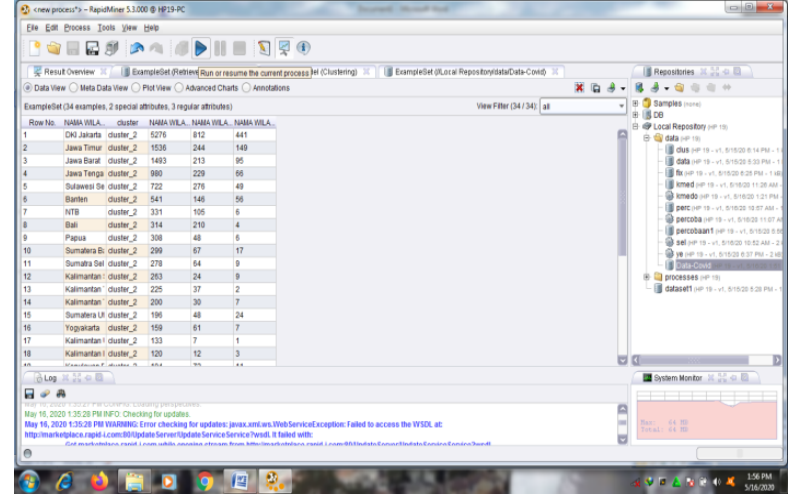

Gambar 17. Proses RUN

Tampilan Meta Data, disini kita bisa melihat jumlah dari cluster integer yang kita gunakan tadi di awal masukan data.

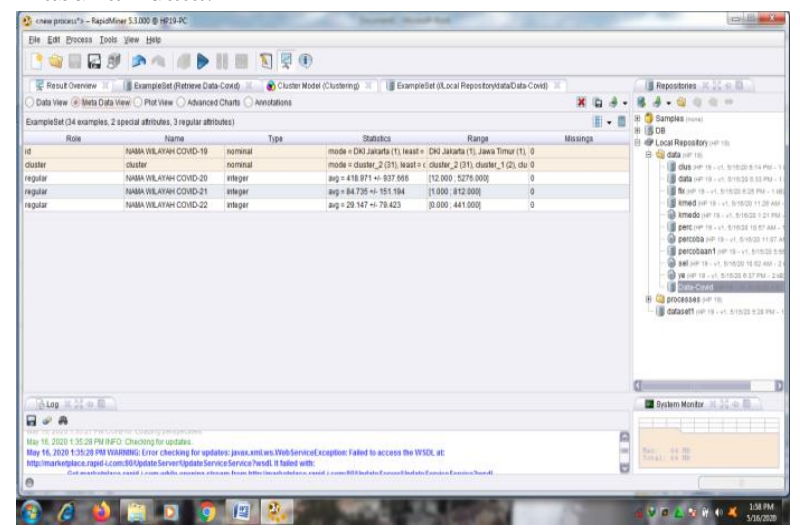

Gambar 18. Meta Data View

Dibagian Plot View kita dapat melihat garis dimana penentuan jumlah kelompok clustering yang ada di setiap daerah. Untuk tampilan plot view disebelah bagian kiri untuk $\mathrm{x}$-Axis, $\mathrm{y}$-Axis dan color custum pilihlah (cluster) semua yang akan terlihat pada gambar di bawah ini. Pada Plot View kita dapat mengetahui bagian-bagian kelompok mana saja yang mendapatkan posisi clustering tingkat 1, 2 dan 3

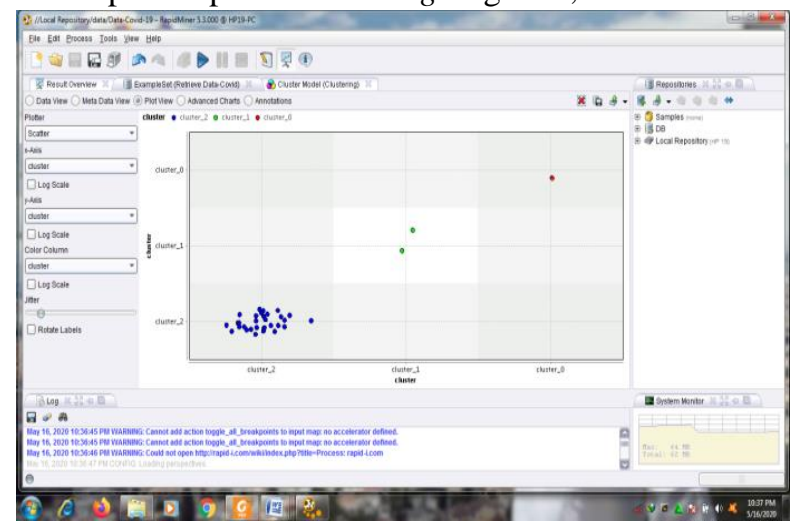

Gambar 19. Plot View dan hasil akhir

Pada gambar diatas ini adalah tampilan akhir dari penerapan K-Medoids untuk menentukan pengelompokan data clustering. Dari hasil pengujian di atas, dapat disimpulkan bahwasanya Cluster 0, terdiri dari 1 wilayah. dan cluster 1 terdiri dari 2 wilayah, kemudian cluster 2 terdiri dari 31 wilayah. Dari pengumpulan yang di dapatkan oleh rapitminer ini, dihitung dari cluster terkecil, menengah hingga cluster dengan nilai tertinggi yaitu $\mathrm{C} 1, \mathrm{C} 2$ dan $\mathrm{C} 3$. diketahui pola pemilihan penentuan pengelompokan penyebaran covid-19 di berbagai wilayah di indinesia. K-Medoids merupakan metode Analitis partisional clustering yang bertujuan untuk mendapatkan suatu set $k$-cluster di antara data yang paling mendekati suatu objek dalam pengelmpokan suatu data.. Hasil penelitian pengelompokan penyebaran covid-19 baru menunjukkan bahwa masyarakat yang berasal dari berbagai wilayah di Indonesia.

\section{KESIMPULAN}

Berdasarkan penelitian, implementasi dan pengujian, maka didapat Berdasarkan perhitungan yang telah dilakukan, algoritma K-Medoids dapat melakukan pengelompokan data covid-19 mana saja wilayah yang terinfeksi di wilayah masing-masing-masing dengan pengklasteran terbaik dilakukan dengan 3 cluster. Dari 34 record diperoleh 1 record pada cluster pertama, 2 record pada cluster kedua, 31 record pada cluster ketiga. Dan demikian untuk melakukan proses implementasi pada sistem dan analisis dapat menerapakan percobaan tersebut. Hasil dari percobaan juga dapat diimplementasikan dengan data yang besar dan atribut yang kompleks.

\section{DAFTAR PUSTAKA}

[1] Atmaja, E. H. S. 'Implementation of k-Medoids Clustering Algorithm to Cluster Crime Patterns in Yogyakarta', International Journal of Applied Sciences and Smart Technologies, 1(1), pp. 3344. doi: 10.24071/ijasst.v1i1.1859. 2019.

[2] Juninda, T. and Andri, E. 'Penerapan Algoritma K-Medoids untuk Pengelompokan Penyakit di Pekanbaru Riau', (November), pp. 42-49. 2019.

[3] Kementrian kesehatan Republik Indonesia https.kementrian kesehatan.go.id/data covid-9.

[4] Marlina, D. et al. 'Implementasi Algoritma KMedoids dan K-Means untuk Pengelompokkan Wilayah Sebaran Cacat pada Anak', Jurnal CoreIT: Jurnal Hasil Penelitian Ilmu Komputer dan Teknologi Informasi, 4(2), p. 64. doi: 10.24014/coreit.v4i2.4498. 2018.

[5] Metisen, B. M. and Sari, H. L. 'ANALISIS CLUSTERING MENGGUNAKAN METODE KMEANS DALAM PENGELOMPOKKAN PENJUALAN PRODUK PADA SWALAYAN 
FADHILA', 11(2), pp. 110-118. 2015.

[6] Pramesti, D. F. et al. 'Implementasi Metode KMedoids Clustering Untuk Pengelompokan Data', Jurnal Pengembangan Teknologi Informasi dan Ilmu Komputer, 1(9), pp. 723-732. doi: 10.1109/EUMC.2008.4751704. 2017.

[7] Pulungan, N., Suhada, S. and Suhendro, D. 'Penerapan Algoritma K-Medoids Untuk Mengelompokkan Penduduk 15 Tahun Keatas Menurut Lapangan Pekerjaan Utama', KOMIK (Konferensi Nasional Teknologi Informasi dan Komputer), 3(1), pp. 329-334. doi: 10.30865/komik.v3i1.1609. 2019.

[8] Silitonga, D. A., Windarto, A. P. and Hartama, D. 'Penerapan Metode K-Medoid pada Pengelompokan Rumah Tangga Dalam Perlakuan Memilah Sampah Menurut Provinsi', Seminar Nasional Sains \& Teknologi Informasi (SENSASI) SENSASI 2019 ISBN:, pp. 313-318. 2019.

[9] Wira, B., Budianto, A. E. and Wiguna, A. S. 'Implementasi Metode K-Medoids Clustering untuk Mengetahui Pola Pemilihan Program Studi', Jurnal Terapan Sains \& Teknologi, 1(3), pp. 5469. 2019.

[10]Zayuka, H., Nasution, S. M. and Purwanto, Y. 'Perancangan Dan Analisis Clustering Data Menggunakan Metode K-Medoids Untuk Berita Berbahasa Inggris Design and Analysis of Data Clustering Using K-Medoids Method For English News', e-Proceeding of Engineering :, 4(2), pp. 2182-2190. 2017. 